\title{
MEETINGS
}

VIITH WORLD Congress of ANAESTHESIOLOGY 14-21 Sepiember, 1980 Hamburg, Germany

For Information:

Dr. K. Horatz

Hamburg Messe und Congress

Junguiusstrasse

2000 Hamburg 36

Germany

Contact:

Mr. U.H. Schulze

Kuehne \& Nagel Travel

371 rue St. Jacques

Montreal, Quebec

H2Y IN9

(514) 842-9731

\section{Canadian Anaesthetists' Society} OnTARIO Division

Ontario Medical Association

Anaesthetic Section

Annual Fall Meeting

September 26-28, 1980

Airline Hotel, Thunder Bay, Ontario

For Information:

Dr. J.R. Wilson

328 Catherine Strect

Thunder Bay, Ontario

P7E 1 K7

Canadian Anaesthetists' Society AtLantic Divisions Meeting

October 2-4, 1980

Halifax, Nova Scotia

For Information:

Dr. J.P. Donachie

Chairman

Nova Scotia Division - C.A.S

Highland View Hospital

Amherst, N.S. 8th Annual Scientific Conference SOCIETY OF ANAESTHESIOLOGISTS OF EAST AFRICA

Ocrober $3-5,1980$

Nairobi, Kenya

For Information:

Dr. C.J. Omondi Nyayieka

P.O. Box 20792, Nairobi, Kenya

NEW HAMPSHIRE-VERMONT SOCIETY OF ANESTHESIOLOGISTS

November l, 1980

Woodstock Inn, Vermont

For Information:

Dr. John C. Abajian

Secretary-Treasurer, New Hampshire-

Vermont Society of Anesthesiologists

Medical Center Hospital of Vermont

Burlington, Vermont

05401 U.S.A.

Basic Research On The Endorphin System INTERNATIONAL CONGRESS

November $20-21,1980$

University of Nijmegen

The Netherlands

For Information:

Ine Baltussen

Department of Anaesthesiology

University of Nijmegen

Post Box 9101

$6500 \mathrm{HB}$ Nijmegen

The Netherlands 


\section{Ist Asian Aust ralasian Conference on \\ Critical Care Medicine and Advances In Cardio-Pulmonary RESUscitation}

November $22-23,1980$

Vigyan Bhavan, New Delhi-110001, India

Biennial Congress of the South African Society of ANAESTHETISTS

March 21-26, 1981

Plettenberg Bay, South Africa

For Information:

Dr. D.F. Morrell

Department of Anaesthetics

Medical School

Observatory 7925

Cape Town, South Africa

ISRAEL SOCIETY OF ANAESTHESIOLOGISTS 12TH CONGRESS

April 13-16, 1981

Herzlia-on-Sea, Israel

For Information:

Secretariat

P.O.B. 3473

Tel Aviv, Israe!
Seventeenth Biennial Western

CONFERENCE ON ANESTHESIOLOGY

COMBINED CONFERENCE AND

Post-Conference Seminar

May 3-7, 1981

The Hawaiian Regent Hotel, Waikiki, Hawaii

May 8-9, 1981

Intercontinental Hotel, Maui, Hawaii

For Information:

Murrary G. Atnikov, M.D.,

Secretary-Treasurer

Biennial Western Conference on

Anesthesiology

Suite 206, 600 Royal Avenue

New Westminster, B.C.

Canada. V3M $1 \mathrm{~J} 3$

\section{Canadian Anaesthetists' Society}

June $13-18,1981$

$$
\begin{gathered}
\text { Annual Meeting } \\
\text { Hotel Nova Scotia } \\
\text { Halifax, Nova Scotia }
\end{gathered}
$$

For Information:

Honorary Secretary

178 St. George Street

Toronto, Ontario

M5R 2M7

SECOND INTERNATIONALSYMPOSIUM ON

ENDOCRINOLOGY IN ANESTHESIA AND SURGERY

\section{September 1981}

$$
\text { Kyoto, Japan }
$$

For Information:

Dr. T. Oyama

Dept. of Anesthesiology

University of Hirosaki School of Medicine

Hirosaki, Aomori-ken, 036, Japan 


\section{Second Asian Congress of}

ANAESTHESIOLOGISTS

September $11-13,1981$

Kuala Lumpur, Malayasia

For Information:

Dr. S.W. Lim

Malayasian Society of Anaesthesiologists

MMA Secretariat

PO Box S-20 Sentul

124 Jalan Pahang

Kuala Lumpur 02-14

Malaysia 